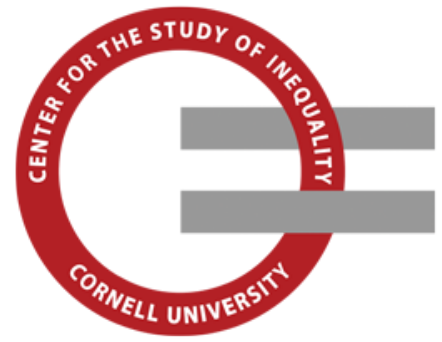

Center for the Study of Inequality Cornell University

363 Uris Hall

Ithaca, NY 14850

(607)254-8674

inequality@cornell.edu

www.inequality.cornell.edu

\title{
Stutter-Step Models of Performance in School
}

Stephen L. Morgan

Cornell University

Theodore S. Leenman

Harvard University

Jennifer J. Todd

Kentucky Department of Education

Kim A. Weeden

Cornell University

Final version published as: Morgan, Stephen L., Theodore Leenman, Jennifer Todd, and Kim A. Weeden. 2013. Stutter-Step Models of Performance in School. Social Forces 91(4):14511474.

Copyright: This is a pre-copyedited, author-produced version of an article accepted for publication in Social Forces following peer review. The version of record is available online at: https://doi.org/10.1093/sf/sot037.

This article is brought to you free and open access by the Center for the Study of Inequality Collection in eCommons@cornell.edu.

Follow this and additional works at: https://ecommons.cornell.edu/handle/1813/52084 


\title{
Stutter-Step Models of Performance in School* (forthcoming, Social Forces)
}

\author{
Stephen L. Morgan \\ Cornell University \\ Theodore S. Leenman \\ Harvard University \\ Jennifer J. Todd \\ Kentucky Department of Education \\ Kim A. Weeden \\ Cornell University
}

January 24, 2013

(Prior drafts: November 22, 2011; March 25, 2012; July 25, 2012)

\footnotetext{
* Direct correspondence to Stephen L. Morgan (morgan@ @ornell.edu) at Department of Sociology, 323 Uris Hall, Cornell University, Ithaca, NY 14853. We thank Thomas Barnes, Shenell Bourne, Elissa Cohen, Catherine Pimentel, Amanda Pinto, and William Tannanbaum for their research assistance as well as colleagues at Duke, Minnesota, Ohio State, Princeton, and Wisconsin for their enriching comments. This research was supported by the National Science Foundation (SBES-1023798) and by a Visiting Fellowship for Morgan at Collegio Carlo
} 
Alberto. Opinions reflect those of the authors and do not necessarily reflect those of the granting agencies. 


\title{
Stutter-Step Models of Performance in School
}

\begin{abstract}
To evaluate a stutter-step model of academic performance in high school, this article adopts a unique measure of students' beliefs that is constructed from two matched sources of information on 12,591 high school sophomores from the Education Longitudinal Study (ELS), 2002-2006. Verbatim responses to questions on occupational plans are coded into 1,111 categories in order to capture detailed information (specific job titles), extended information (the listing of multiple jobs), and contradictory information (the listing of multiple jobs with divergent characteristics). The educational requirements of detailed jobs, as specified in the Department of Labor's O*NET database, are then matched to all jobs that students list within their plans. Subsequent analysis demonstrates that students with uncertain beliefs have (1) lower levels of performance in both the sophomore and senior years of high school, net of adjustments for family background and expectations for future education, and (2) lower commitment to schooling, as measured by 32 indicators of achievement-relevant behavior reported by students, parents, and teachers. These results support the conjecture that uncertainty about the future has consequences for the short-run behavior that determines important educational outcomes, beyond the effects that are commonly attributed to existing models of performance.
\end{abstract}




\section{Stutter-Step Models of Performance in School}

Performance in high school is a strong predictor of college attendance and other lifecourse outcomes that structure inequality in the United States. The extant educational attainment literature amply demonstrates that performance is strongly predicted by family background, with effects commencing in early childhood and continuing throughout educational careers. A more recent literature shows that performance in high school, in particular, is also structured by adolescents' decisions about whether to commit to the student role and to engage with the content of their coursework, decisions that are partly but not wholly conditioned by family background.

No consensus exists in the literature on how these contingent and consequential everyday decisions should be modeled. In this article, we build the case for a "stutter-step model" of student performance in high school that has four basic premises: (1) high school performance is determined, to a substantial degree, by everyday decisions to commit to schooling; (2) commitment decisions are oriented to the future; (3) the beliefs that structure these forwardlooking decisions may be inaccurate and uncertain; (4) as a result, the factors that structure beliefs may have autonomous effects on performance by way of everyday commitment decisions, net of family background and other fixed characteristics of individuals.

One focus of the stutter-step model is thus on the consequences of uncertainty and inaccuracy of beliefs about the future on performance in high school. Important precursors to this model exist, including models in the broad literature on engagement that emerged in the late 1980s (for a review, see Fredericks, Blumenfeld, and Paris 2004), the "aligned ambitions"

lifecourse model of schooling proposed by Schneider and Stevenson (1999), and, more recently, 
Morgan's (2005) model of prefigurative and preparatory commitment (see also Morgan, Leenman, Todd, and Weeden 2013). This emphasis on uncertainty and inaccuracy has become increasingly prominent in recent literature in the sociology of education as well (see Bozick, Alexander, Entwisle, Dauber, and Kerr 2010; Grodsky and Riegle-Crumb 2010; Staff, Harris, Sabates, and Briddel 2010; Yates, Harris, Sabates, and Staff 2011). The stutter-step model falls solidly within this broader research agenda, but moves it forward by focusing on the mechanism through which uncertainty affects performance.

As explained in the next section, we will evaluate the tenability of the four-part stutterstep model of student performance. To do so, we employ a unique measure of the uncertainty of high school sophomores' beliefs about the future. This measure is constructed from our own coding of the verbatim responses of 12,591 high school sophomores from the restricted-access data records of the Education Longitudinal Study (ELS), 2002-2006. We show that this new measure predicts both everyday commitment decisions and academic performance in high school.

\section{A Causal Graph for Performance in High School}

Figure 1 presents the underlying causal model that will motivate our empirical analysis, a model in the new causal graph tradition (Pearl 2009). ${ }^{1}$ Observed variables are represented by solid nodes, $\bullet$, and unobserved variables by hollow nodes, ○. Arrows represent assumed causal effects, and no assumptions of linearity or separability are built into the model. Accordingly, causes can have nonlinear effects on outcomes, and causes can interact with each other in producing effects. In this article, the black arrows represent causal effects that we assume exist.

\footnotetext{
${ }^{1}$ See Morgan and Winship (2007) for an introduction to causal graphs written for social scientists and Morgan et al. (2013) for two related causal graphs.
} 
The gray arrows represent causal effects that many other researchers assume exist and which we accordingly allow even if, as we discuss below, we are not convinced that they exist.

\section{[INSERT FIGURE 1 ABOUT HERE]}

For the causal graph in Figure 1, Family Background represents the five standard measured variables for socioeconomic status (mother's education and occupational prestige, father's education and occupational prestige, and family income) as well as demographic characteristics of students and their families. The final outcome, Performance, represents four related measures of high school performance, all of which will be analyzed in this article: a standardized test in reading in 2002 (the sophomore year of high school for ELS respondents), a standardized test in mathematics in 2002, a standardized test in mathematics in 2004 (usually the senior year), and the student's cumulative grade point average by 2004 .

The model asserts that performance in high school is caused by a direct effect of family background and by a general mechanism represented by a chain of three unmeasured variables: information $(I)$, beliefs $(B)$, and commitment $(C){ }^{2}$ This mechanism is intended to capture a welldocumented phenomenon in adolescence: many students move in fits and starts through high school, eschewing all-or-nothing grand decisions about their futures and responding only in a limited way to the educational plans defined for them by others. Students make consequential everyday choices of whether to commit to schooling, and they do so under information deficits

\footnotetext{
${ }^{2}$ The direct effect of family background on performance is properly interpreted as a collection of unspecified mechanisms. We take no position on which of the many proposed mechanisms in the literature constitutes a portion of the arrow that defines this direct effect in Figure 1. Possibilities include (1) differences in resources that affect learning and performance but that are unrecognized by students, (2) biased assessments of teachers that generate an association between ascriptive characteristics such as race and subjective performance evaluations such as grades on written assignments, and (3) structures in schools, such as tracking and course sequences, that harm the achievement growth of students from disadvantaged social origins, without such students recognizing these effects. Notice, however, that we do give the Wisconsin model an explicit place in the causal graph, which includes its master variable of educational expectations (see Sewell, Haller, and Portes 1969; Sewell, Hauser, Springer, and Hauser 2004). Accordingly, the Wisconsin model mechanism, where significant others define status expectations that students then adopt as their own aspirations, is not embedded within the direct effect arrow that emanates from family background.
} 
and with goals that are susceptible to social influence (see Bozick et al. 2010; Fredericks et al. 2004; Grodsky and Riegle-Crumb 2010; Morgan 2005; Schneider and Stevenson 1999).

The causal graph in Figure 1 (see also Morgan et al. 2013, Figure 2) posits that the unmeasured information, $I$, that informs educational choices is generated by exogenous factors in $Z$ and $V .^{3}$ This information, which presumably includes information about the fairness of the education system and about the costs and benefits of higher education, is also determined directly by family background. We assume that this effect of family background on $I$ emerges because those who occupy advantaged social positions are more comfortable searching for information beyond that which is available to them because of joint structural determinants, $V$, of both family background and the distribution of information.

Beliefs, $B$, are then formed on the basis of this differentially available information, although in interaction with family background. Here we assume that students from different family backgrounds may process their acquired information differently. They may also feel that the costs and benefits of education depend on their social origins. This perception may or may not be accurate, and indeed the academic literature offers contradictory findings regarding the direction and magnitude of class-differentiated costs and benefits (see Breen and Goldthorpe 1997 and Brand and Xie 2010). For our purposes, the critical point is not so much whether beliefs about education are accurate, only that these beliefs vary by both family background and information, $I$.

The key mechanistic behavioral variable in the causal model is commitment, $C$, which transmits the effects of beliefs to performance in high school. Figure 1 does not require any one

\footnotetext{
${ }^{3}$ Typically in this tradition of causal graphs, nodes such as $Z$ would be suppressed, since it is assumed that all nodes have exogenous sources that give them distributions and that are independent of the other variables in the model. Here, we give $Z$ an explicit place in the model in order to reinforce the point that differences in information are not reducible to differences in family background or correlates of it.
} 
particular model of commitment, and there are many on offer. Morgan (2005) provides one possible model in his concepts of prefigurative and preparatory commitment, where the latter follows from the former. A second possible model of commitment emerges from the "aligned ambitions" perspective (Schneider and Stevenson (1999). This model maintains that motivation and effort in high school are determined partly by the alignment of students' educational and occupational ambitions, which Schneider and Stevenson argue are shaped by a diverse set of factors that structure students' beliefs about their futures. A third alternative is the Bourdieuinspired model of habitus used by Grodsky and Riegle-Crumb (2010:18), where "a college-going habitus may increase the likelihood that students engage in behaviors that increase their probability of attaining their goals." For Grodsky and Riegle-Crumb, a college-going habitus can be measured by indicators of how beliefs for future educational attainment were constructed, either as taken-for-granted scripts for the future or as conscious choices arrived at during primary or secondary schooling. The critical point here is not which model of commitment the analyst adopts, but that he or she adopts some belief-based model of everyday behavioral orientations to schooling that can account for some subsequent differences in levels of educational performance.

Finally, the causal graph in Figure 1 includes two additional observed variables that reflect the underlying beliefs in $B$. As discussed in the next section, Educational Requirements of Expected Jobs will be the key predictor variable in our empirical models, and College Expectations will be used to test for the robustness of our conclusion that the underlying model of commitment has empirical support.

\section{Empirical Strategy}


How can this stutter-step mechanism be evaluated? Our empirical strategy has a simple goal: to determine whether evidence supports the existence of the causal pathways $I \rightarrow B \rightarrow C \rightarrow$ Performance. The empirical challenge is that $I, B$, and $C$ are either partly or completely unobserved.

We resolve this challenge, we argue, by using a unique measure of students' beliefs that is represented in Figure 1 by Educational Requirements of Expected Jobs. Nominally, this measure is based on a fine-grained coding of students' verbatim occupational plans, matched to an external source of information on whether the expected job(s) typically require a college degree. This measure, as we detail below, allows us to separate students with specific and certain beliefs about their futures from those with uncertain beliefs and/or internally inconsistent beliefs.

The rationale for our evaluation is based on the causal relations encoded in Figure 1, which represent assumptions grounded in theory and informed by past empirical research. To the extent that students (a) formulate beliefs about the costs, benefits, and other characteristics of higher education based on information that is differentially available to them, and (b) make everyday commitment decisions that are consistent with these beliefs, our measured variable Educational Requirements of Expected Jobs captures some of the variation in beliefs, $B$, as well as uncertainty in these beliefs. Variation in Educational Requirements of Expected Jobs provides leverage to assess the importance of the causal pathway $I \rightarrow B \rightarrow C \rightarrow$ Performance. Our first two empirical questions are therefore:

1. Do the educational requirements of expected jobs, and any inherent uncertainty within them, predict high school performance? 
2. Does any such association persist after the back-door associations that are generated by the paths $B \leftarrow$ Family Background $\rightarrow$ Performance, $B \leftarrow I \leftarrow$ Family Background $\rightarrow$ Performance, and $B \leftarrow I \leftarrow V \rightarrow$ Family Background $\rightarrow$ Performance are blocked by conditioning on family background?

If the answers to these two questions are affirmative, the analysis supports the case for a contingent belief-based mechanism that generates performance, since even the exogenous sources of information in $Z$ have consequences for performance by way of $I, B$, and $C$. To foreshadow our results, we show that these unconditional and conditional associations not only exist, but are quite substantial.

Our third empirical question suggests a robustness check against the main competing interpretation of our results, namely that the unconditional and conditional associations between Educational Requirements of Expected Jobs and Performance can be attributed to college expectations, perhaps the most important causal variable in status attainment models of achievement and attainment (see Sewell, Haller, Portes 1969; Sewell, Hauser, Springer, and Hauser 2004). We will therefore evaluate the question:

3. Can the conditional association between Educational Requirements of Expected Jobs and Performance, especially the portion that picks up the effects of uncertainty of beliefs about the future, be accounted for by College Expectations?

In the analysis that follows, we show that college expectations can account for some, but not all, of the conditional associations between Educational Requirements of Expected Jobs and Performance. This result suggests that the association between beliefs about educational requirements and performance is independent of the processes implied by the dominant model of attainment in the sociological literature. 
After building the case that our measure Educational Requirements of Expected Jobs predicts performance in ways that cannot be explained away by prominent alternative explanations, we introduce 32 separate measures of commitment to schooling into the analysis. These measures allow us to demonstrate that the variation in Educational Requirements of Expected Jobs that predicts performance is also associated with everyday commitment decisions, consistent with the assumed causal structure of the stutter-step model. We interpret these final results as evidence for the claim that commitment, $C$, is a plausible mechanism for the effects of information, $I$, and beliefs, $B$, on measured performance.

\section{METHODS}

Data were drawn from the 2002 base-year, 2004, and 2006 follow-up waves of the ELS, a nationally representative sample of students in public and private high schools collected by the National Center for Education Statistics (NCES). We analyze the panel sample, which includes 12,591 respondents who participated in all three rounds of the survey. The data are weighted by the base-year and second follow-up panel weight (F2BYWT, developed by the data distributors), multiplied sequentially by two estimated inverse probabilities that account for non-random participation in all three waves of the survey and for missing data on the variable that is the outcome for each model presented. The estimated probabilities were drawn from separate logit models that predict inclusion in the panel and also non-missingness of the respective dependent variables.

\section{RESULTS}


Table 1 presents our measures of performance and our primary explanatory variable,

Educational Requirements of Expected Jobs. Panel (a) presents the means and standard deviations for math and reading test scores in 2002, math test scores in 2004, and cumulative high school GPA in 2004. The test scores are IRT-scaled "estimated number right" scores, and the math test scores are scaled so that they can be compared across waves. (No reading test was given in 2004.)

\section{[INSERT TABLE 1 ABOUT HERE]}

Panel (b) of Table 1 presents our measured variable for Educational Requirements of Expected Jobs. Because this variable is our core predictor variable, its construction requires some explanation. Question 64 of the 2002 ELS self-administered sophomore student questionnaire instructed respondents to "Write in the name of the job or occupation that you expect or plan to have at age 30." Respondents made one of four choices: write in a response, select "I don't plan to work when I'm 30," select “I don't know," or skip the question. The data processors contracted by the U.S. Department of Education coded responses to this prompt into an occupational plans variable with seventeen categories. Each of the seventeen categories is broadly consistent with census major occupation groups (e.g., craft, professional), with the additional differentiation of "professional A" from "professional B" and of separate categories for "school teacher," "protective service," and "other."

The data distributors also provided the verbatim responses to question 64 as metadata available to approved users of the restricted-access ELS data. We assembled our own team to code components of these verbatim occupational plans into 1,111 distinct categories. We coded each occupation listed within the verbatim response, using extended versions of the 2000 Standard Occupational Classification (SOC) and the 2002 Occupational Information Network 
(O*NET) database produced by the U.S. Department of Labor. We then matched the categories in our coding of jobs to the $\mathrm{O}^{*} \mathrm{NET}$ database to obtain the educational requirements of all of the expected jobs listed within each students' occupational plans. ${ }^{4}$

Panel (b) of Table 1 presents our categorization of these responses after they were matched to the educational requirements of students' expected jobs. As shown in the first row, 42.0 percent of respondents listed only jobs that required at least a bachelor's degree or more of education. Many of these respondents listed multiple jobs, but all of these jobs required at least a college degree. In contrast, 11.5 percent of respondents listed jobs that all required at most a high school degree. ${ }^{5}$

Two categories of respondents expressed variably uncertain plans. First, 3.9 percent of respondents offered two or more jobs, of which at least one required a college degree and at least one required no more than a high school degree. Second, 30.9 percent of respondents selected the response option of "I don't know." "These two groups of respondents are the most important for our analysis, and together they represent more than one third of the sample.

\footnotetext{
${ }^{4}$ In order to merge in the $\mathrm{O}$ *NET educational requirement information, we collapsed our 1,103 job codes (i.e., all but the single "uncodable" category for a verbatim response and 7 distinct codes for types of missingness) into 339 broader categories across which educational requirement information is made available in the O*NET as job zones. ${ }^{5}$ To classify each job listed as a "College or more" job or a "High school or less" job, we dichotomized the O*NET job zone classification between 3 and 4 on the scale from 1 to 5 . As a result, the "College or more" jobs are those that have Specific Vocational Preparation (SVP) of 7.0 or higher and are characterized by "considerable preparation needed" such that "most of these occupations require a four-year bachelor's degree" (see URL:

http://www.onetonline.org/help/online/zones). Likewise, the "High school or less" jobs had corresponding SVP of less than 7.0, and yet include some jobs that may require post-secondary training less substantial than a bachelor's degree. Like all exercises in dichotomization, noise is inevitable, with some misclassification of jobs near the cutpoint on the job zone scale. Still, focusing narrowly on the job zone breakpoint of requiring skills typically held by those with bachelor's degrees, underpinned by SVP ratings, made the most sense to us based on our theoretical conceptualization.

${ }^{6}$ With reference to results reported in Staff et al. (2010) and Yates et al. (2011), the rate of "don't know" responses is higher in the ELS data than in the National Education Longitudinal Study of 1988 (NELS) and the British Cohort Study of 1970 (BCS70). We have no way of knowing whether this is because uncertainty of occupational plans is greater in the United States than the UK, or greater in the US in recent cohorts, or whether it is because our measure is based on a free response whereas the NELS and BCS70 use forced-choice response categories. Staff et al. (2010) offer a typology of explanatory models that predict alternative profiles of occupational aspirations, following directly on the work of Schneider and Stevenson (1999) and related work in lifecourse studies. Some of these models suggest that higher levels of uncertainty should be more common in the United States, and increasing since
} 
Less than one percent of respondents indicated that they did not plan to work at age 30 . Eleven percent of respondents did not respond in any way to the question, and less than one percent provided a response that we judged uncodable, either because it was a nonsensical string of characters, which we assume resulted from poor handwriting, or was an obvious wisecrack. ${ }^{7}$

\section{Beliefs and High School Performance}

Tables 2 and 3 provide results that answer our three primary research questions. Table 2 presents six models that predict performance in the sophomore year of high school, where performance is measured by scores on standardized tests of reading and mathematics in 2002. Table 3 presents analogous models for math performance measured two years later and for cumulative GPA across all years of high school. (As detailed below, we also offer in a Supplementary Appendix additional models that assess math learning, measured as the difference between 2004 and 2002 math test scores, as well as timely high school graduation.)

\section{[INSERT TABLES 2 AND 3 ABOUT HERE]}

Question 1. Do the educational requirements of expected jobs, and any inherent uncertainty within them, predict high school performance? Models 1 and 4 presented in Table 2 and Models 7 and 10 presented in Table 3 suggest that the answer to this question is $\underline{\text { Yes. Model }}$ 1 regresses the 2002 math test score for high school sophomores on dummy variables for the categories of our variable Educational Requirements of Expected Jobs, where the "College or more" category is the reference group. The coefficient for the "High school or less" category is 7.44 and suggests that those who do not expect to be in a job that requires anything beyond a high school degree have lower levels of math performance in the tenth grade (approximately one

the 1970s, because of high absolute levels of, and unusually rapid growth in, labor market inequalities.

${ }^{7}$ See Morgan et al. (2013) for a similar but more finely differentiated coding of twelfth grade occupational plans. 
half of a standard deviation or 7.44/14.11). Although not our primary interest, this contrast in performance conforms to most theoretical predictions.

Our primary interest lies instead in the coefficients for the two uncertain categories of "High school and college" and "Don't know," since these groups of students hold beliefs that are uncertain, possibly based on inaccurate or inadequate information. The coefficients of -3.53 and -4.43 indicate substantial negative associations, at one quarter or more of a standard deviation of the underlying test score distribution, and both are high multiples of their estimated standard errors, making it very unlikely that they result from sampling error. Instead, they indicate that high school sophomores with uncertain beliefs about their occupational futures have lower levels of math performance in the sophomore year. Models 4, 7, and 10 demonstrate that the same pattern holds for reading performance in the tenth grade, math performance two years later, and for cumulative grade point average by $2004 .^{8}$

The answer to Question 1 is therefore Yes in two specific senses. First, the higher the level of education required for an expected job, the higher the student's performance in high school. Second, students who (a) listed two or more expected jobs with inconsistent required levels of education or (b) were willing to indicate explicitly their uncertainty (by selecting "I don't know" in response to the prompt for occupational plans) performed worse than those who listed only expected jobs that required college degrees.

Questions 2 and 3. The remaining models in Tables 2 and 3 assess whether the associations in Models 1, 4, 7, and 10 can be accounted for by family background and college expectations. The goal of these additional models is to determine whether the evidence for our

\footnotetext{
${ }^{8}$ We will not interpret the remaining categories of respondents here or at any point in this article. We simply note that those without plans to work at age 30 have low performance, although their performance is imprecisely estimated because this group is very small. The "Missing" and "Uncodable" categories have the sort of low performance that is typical of respondents who do not comply with surveys, either because they cannot or choose not to.
} 
affirmative response to Question 1 is at least partly separable from evidence that could be used to support standard alternative interpretations of the overall associations.

Models 2, 5, 8, and 11 adjust for 26 variables that measure family background, related demographic characteristics, and school sector. Means and standard deviations for these adjustment variables are presented in Appendix Table A1. Overall, the adjusted models explain much more of the variance of the performance measures, as indicated by the R-squared values in the second to last row of each table. More critically, at least for our purposes, the net associations for the categories of Educational Requirements of Expected Jobs are reduced in magnitude but remain substantial and would still be judged statistically significant by conventional hypothesis tests.

Accordingly, the answer to Question 2 is $\underline{\text { Yes }}$ as well. After using 26 available measures in an attempt to block the back-door paths that connect underlying beliefs, $B$, to Performance ( $B$ $\leftarrow$ Family Background $\rightarrow$ Performance, $B \leftarrow I \leftarrow$ Family Background $\rightarrow$ Performance, and $B$ $\leftarrow I \leftarrow V \rightarrow$ Family Background $\rightarrow$ Performance), the association between our manifest indicator of beliefs and performance remains, with the usual caveat that measurement is imperfect and some back-door confounding may remain. This result suggests that even if we make a very restrictive assumption about the scope of the stutter-step mechanism - the portion of the mechanism that originates in basic family background processes cannot be used as support for it - the remainder of the mechanism still generates a conditional association between Educational Requirements of Expected Jobs and Performance.

Models 3, 6, 9, and 12 further adjust for college expectations, entering in dummy variables for responses to the standard educational expectations question: "As things stand now, how far in school do you expect to get?" With "Bachelor's degree or higher" as the reference 
category, these additional adjustment variables are very strongly predictive, as has been shown in more than four decades of prior research. Those who expect lower levels of education, or who do not know how far in school they will "get," have lower levels of performance. The conditional associations between Educational Requirements of Expected Jobs and Performance decline further, but they remain substantial and statistically significant by conventional standards.

Our answer to Question 3 is therefore also Yes. Even if we take away the portion of the association between $B$ and Performance that may be generated by the potential causal pathways (1) $B \rightarrow$ College Expectations $\rightarrow$ Performance and (2) $B \rightarrow$ Educational Requirements of Expected Jobs $\rightarrow$ College Expectations $\rightarrow$ Performance, the case for the importance of a contingent belief-based mechanism remains. The standard status attainment model, which funnels all prior effects through educational expectations, cannot account for the determinants of performance reflected in our measured variable Educational Requirements of Expected Jobs. ${ }^{9}$

Two additional points should be noted. First, our variable for college expectations gives these expectations even more potential explanatory power than in the Wisconsin model. Specifically, our ELS variable for college expectations has its own "Don't know" category, which was a valid response for the ELS questionnaire. (Interestingly, the Wisconsin Longitudinal Study had a similar response category - "I have no definite plans" - but it was not treated as an informative response when scaling students' Level of Educational Aspiration for the Wisconsin model articles. ${ }^{10}$ ) As a result, our college expectations variable adjusts for both the

\footnotetext{
${ }^{9}$ When combined with the last set of results, this new result suggests that, at a minimum, the exogenous sources of information in $Z$ that do not work their way sympathetically to College Expectations have consequences for performance by way of the causal pathway $I \rightarrow B \rightarrow C \rightarrow$ Performance.

${ }^{10}$ The 1957 questionnaire for the Wisconsin Longitudinal Study (WLS) had a nonstandard format for elicitation, and it is unclear to us how the questions on college plans were combined into the college plans variables that were utilized for the published research. Nonetheless, it seems that for the two classic Wisconsin model articles, college plans were restricted to levels of education expected (first, for the 1969 article, as a binary variable for any type of
} 
level of one's educational expectation and for uncertainty about one's future educational trajectory. ${ }^{11}$ Models 3, 6, 9, and 12 imply that the uncertainty reflected in occupational plans may decrease everyday performance even for students whose uncertainty has not reached a level that prompts them to select a "Don't know" response when asked whether or not they expect to enter college.

Second, educational expectations have increased considerably since the 1960s, and perhaps in fantastical ways that reduce their explanatory utility (see Goyette 2008; Morgan 1998; Reynolds, Steward, MacDonald, and Sischo 2006). Accordingly, it is possible that a new indicator of "educational aspirations" is needed in order reveal the true explanatory power of the Wisconsin model for today's youth. Such a measure would need to elicit educational expectations that are not contaminated by the possible existence of a "college for all" ethos (see Rosenbaum 2001). We know of no such measure.

Commitment as a Mechanism. Now that we have demonstrated that the association between Educational Requirements of Expected Jobs and Performance is robust, we consider whether commitment, $C$, can be considered the carrier of the effects of beliefs, $B$, to Performance, as implied by the stutter-step model. To assess whether the ELS data are consistent with the claim that such a causal mechanism operates, we now utilize 32 separate indicators of commitment to schooling drawn from items on the questionnaires completed by students, parents, and teachers. Students were asked questions such as "How often do you come to class without these things," followed by three prompts: "pen/pencil or paper," "books," and "homework done." Respondents to the parent questionnaire were asked questions such as "Since

college or degree granting institution relative to no further education and second, for the 1970 article, after creating a third middle category for those who planned to attend postsecondary vocational schools).

${ }^{11}$ The source variable in the ELS is the composite variable BYSTEXP, for which item-specific missing values on the original question 56 were imputed by the data distributors. Values of "Don't know" were not imputed and were all selected by respondents. 
your tenth grader's school opened last fall, how many times have you or your spouse/partner been contacted by the school about the following?" also followed by three prompts: "your tenth grader's problem behavior at school," "your tenth grader's poor attendance record at school," and "your tenth grader's poor performance in school." Finally, teachers were asked questions such as, "Does this student usually work hard for good grades in your class?" and "Has this student fallen behind in school work?" (Full details and question wordings for these items are presented in Supplementary Appendix Tables S1-S6.)

A standard approach for using these 32 variables to evaluate the plausibility of a commitment mechanism would be to create a unidimensional commitment index and then assess whether this index variable can explain away some of the association between Educational Requirements of Expected Jobs and Performance (e.g., as in the "work habit" scale of Farkas, Grobe, Sheehan and Yuan 1990, the "effort" scale of Carbonaro 2005, or the "behavioral engagement" scales reviewed by Fredericks et al. 2004). Taking a similar strategy, we proceed in two steps, reported in Tables 4 and 5.

For the first step, Table 4 specifies three models with a factor-scored, unidimensional index of commitment as the outcome variable. Each of the 32 commitment variables was treated as an indicator of a latent construct for commitment, which was then scaled to have a mean of zero and standard deviation of one. ${ }^{12}$ The first model (Model 13) in Table 4 shows that our primary categories of interest - "High school and college" and "Don't know" - have coefficients of -.25 and -.29 , suggesting that these two groups have levels of commitment that, according to the index, are approximately one-quarter of a standard deviation lower than for the "College or

\footnotetext{
${ }^{12}$ Scoring for the index was based on the first factor from the default factor routine in Stata (v. 12.0), using imputed versions of all 32 indicators presented in Tables S1-S6. The resulting standardized index is nonetheless left-skewed, with a skewness coefficient of -1.15 and percentiles equal to $-3.1\left(1^{\mathrm{st}}\right),-1.9\left(5^{\text {th }}\right),-.6\left(25^{\text {th }}\right), .20\left(50^{\text {th }}\right), .75\left(75^{\text {th }}\right)$, and $1.23\left(95^{\text {th }}\right)$, and $1.43\left(99^{\text {th }}\right)$.
} 
more" group. Other group differences parameterized by Model 13 suggest that beliefs are generally associated with commitment in expected patterns. Model 14 adjusts for background and school sector while Model 15 adjusts for educational expectations as well. Group differences in commitment decline after these additional adjustments, but they remain substantial and statistically significant at conventional levels.

\section{[INSERT TABLES 4 AND 5 ABOUT HERE]}

Having demonstrated that a unidimensional index of commitment can be predicted by Educational Requirements of Expected Jobs, we proceed to our second step. Table 5 presents regression models for our four measures of performance that include all 32 indicators of commitment as separate predictor variables. ${ }^{13}$ In particular, we add these variables to Models 3 , 6, 9, and 12 from Tables 2 and 3, which represent our most restricted specifications of the stutterstep mechanism. Even in these models, commitment accounts for substantial variation in performance, beyond adjustments for background, school sector, and college expectations, as can be seen by a comparison between the R-squared values across models (e.g., .35 and .33 for Models 3 and 12 in Table 3 increase to .43 and .63 for Models 3M and 12M in Table 5). Commitment also explains away some of the net group differences defined by Educational Requirements of Expected Jobs, even after these coefficients have been reduced substantially by adjustments for background, school sector, and college expectations. For example, for cumulative GPA, the coefficients for "High school and college" and "Don't know" decline from -.15 and -.09 (see Table 3) to -.08 and -.04 (see Table 5), respectively.

\footnotetext{
${ }^{13}$ Models that include only the unidimensional index of commitment yield very similar results for other coefficients, while imposing the unnecessary assumption of indicator-constant effects. For example, for the GPA model, the coefficients for "High school and college" and "Don't know" groups are -.10 and -.04 [with the coefficient for the index of commitment being .51 (with a standard error of .01) and the model R-squared lower at .58].
} 
Overall, the covariation between commitment and performance reduces the magnitudes of the coefficients for the indicator variables of our key construct, Educational Requirements of Expected Jobs, but it leaves substantial net associations between performance and Educational Requirements of Expected Jobs. If additional measures of commitment and everyday engagement were available, it is possible that the net group differences would be reduced further, perhaps even permitting front-door identification of the causal pathways (see Pearl 2009). Even with the limited measures of commitment available in the ELS, the results in Table 5, when compared to the models from Tables 2 and 3, offer substantial support for the claim that commitment is a plausible causal mechanism for the relationship between beliefs about the future and performance.

\section{Supplementary Results}

Supplementary Appendix Tables S1 to S6 present results that demonstrate the consistency of the association between commitment and beliefs across all 32 indicators of commitment. In particular, these six tables present coefficients for the crucial groups with uncertain beliefs "High School and College" and "Don't know" - for 128 different models structured similarly to those in Table 4, but with each of the 32 indicators as the outcome variable.

Supplementary Appendix Tables S7 and S8 present results that demonstrate the robustness of our results to alternative measures of performance. Table S7 shows that the gain in math test scores between the tenth and twelfth grades is consistent with the analysis of performance levels reported in Tables 2, 3, and 5, such that respondents in the "High school and college" and "Don't know" categories have lower math gains in achievement over the two years. Table S8 shows that the same is true for timely high school graduation, with the odds of finishing 
high school on time in 2004 being substantially lower for respondents in the "High school and college" and "Don't know" categories.

\section{CONCLUSION AND DISCUSSION}

Our empirical analysis is motivated by the goal of assessing the support for a recent model of performance in high school, which we have labeled a "stutter-step model." This model articulates an assumed mechanism that undergirds several new perspectives on educational attainment (see citations in the introduction). This recent literature focuses attention on the contingencies of beliefs about the future and how they influence the educational and occupational trajectories of different types of students. The stutter-step model maintains that everyday commitment decisions are susceptible to the uncertainty and inaccuracy of students' own beliefs about their futures, and that these features of beliefs are structured by the quality and quantity of information available to students.

Not only have we found baseline support for this model by demonstrating that uncertainty of beliefs about the future predicts lower everyday commitment to schooling and subsequent performance in schooling, we have also shown that these associations cannot be attributed to family background or to students' own forecasts of their future education. Accordingly, the associations that we report cannot be explained away by the socialization theory developed long ago for status attainment research or any of the literature that follows from it.

\section{Complementary Perspectives}


In response to calls for greater school effectiveness in the $1980 \mathrm{~s}$, scholars contributing to the "student engagement" literature attempted to identify the determinants of active and inquisitive learning (see Fredericks et al. 2004 for a review). This literature supports some of our results, insofar as it demonstrates how engaged commitment to schooling can have positive effects on student performance. Like our model, it recognized that commitment and engagement are determined in part by "socio-cultural determinants" outside of the school (Newmann, Wehlage, Lamborn 1992:17). This literature did not, however, offer much insight into the genesis of these underlying "socio-cultural determinants" of student engagement. Indeed, because of its policy impetus, the engagement literature focused on how schools can foster modes of learning that transcend adherence to traditional school routines dominated by a pedagogy of recitation and response. It tended to overlook how schools can accentuate baseline engagement differences that originate outside of schools.

Two articles, in particular, demonstrate the importance of such processes. Farkas et al. (1990) showed that teachers reward work habits when assigning grades, beyond how the same work habits shape performance and coursework mastery. As a result, determinants of work habits that arise from sources outside of schooling - such as uncertainty about the future that is generated by incomplete or inaccurate information about higher education - are then amplified by performance assessments constructed by teachers. Gamoran and Nystrand (1992) showed that the effectiveness of teaching differs substantially across curriculum tracks in schools, such that teachers in honors classes frequently engage in "authentic questioning" that deepens student engagement with the content of coursework. In contrast, teachers in remedial classes reserve their interactional authenticity for broader discussions of student life, and they utilize a less effective mode of recitation when teaching coursework content. Because track placement in 
school is determined by past demonstrated levels of engagement and performance, any baseline engagement differences attributable to forces outside of the school will be amplified by withinschool differences in pedagogy.

These results suggest that a policy-based research focus on how teachers and schools can cultivate engagement must rest on a solid foundation of research into how baseline engagement is shaped by social origins and students' locations in the broader structure of social inequality. The more recent literature has taken up this challenge head on. In addition to the stutter-step model, we noted earlier that there are additional complementary perspectives that have been influential.

Schneider and Stevenson (1999) focus their attention on the extent to which adolescents maintain "aligned ambitions," which they define as the concurrence of concrete educational plans and the educational requirements of desired jobs. They write, based on extensive in-depth interviews with adolescents, that

A characteristic of those who have aligned ambitions is that they are more likely to sustain high levels of motivation throughout their high school careers. One reason is because adolescents with aligned ambitions are more capable of identifying their own strengths and weaknesses and of creating their own internal standards of performance. (Schneider and Stevenson 1999:107)

For Schneider and Stevenson, parents play crucial roles in helping students to align their ambitions, in part by shaping their beliefs about the future in ways that then compel appropriate everyday courses of behavior. In contrast to our analysis and the stutter-step model that motivates it, Schneider and Stevenson do not focus on the uncertainty that is reflected in the occupational plans of students. However, it is reasonable to assume that many of the students whom Schneider and Stevenson identified as having misaligned ambitions would fall within the one-third of our sample that either expressed considerable uncertainty about their occupational 
plans or that identified planned occupations with internally heterogeneous educational requirements.

In another complementary perspective, Bozick et al. (2010) investigate the dynamic relationship between expectation formation and performance in schooling. Their data source is the Beginning School Study (BSS), which sampled students from Baltimore who entered school in 1982 and re-interviewed them for 20 years in order to document their entire primary and secondary school careers. Following a lifecourse analysis strategy made possible by the long observation window for BSS respondents, Bozick et al. (2010:2047) conclude that their middleSES students who received "mixed signals about their educational prospects" have a profile of performance that is very similar to the stutter-step model proposed and investigated in this article:

Sometimes these youth do well in school; sometimes they stumble. Over time the signals they receive neither consistently support nor temper an expectation to attend college, and when they report late in high school that they expect to attend college, the extent of their commitment and their ability to follow through are less certain. (Bozick et al. 2010:2047)

Bozick and colleagues did not consider the uncertainty that is reflected in occupational plans, nor did they assess the extent to which middle- and lower-SES students throughout the country might exhibit similar patterns. Our results suggest that this "mixed signals" group of students may be more prevalent throughout high schools in the United States than could be determined with the Baltimore sample of the BSS.

The analyses in this article extend and elaborate on this convergent stream of literature and, in the process, deepen both the status attainment perspective that was proposed in the 1960s and the student engagement perspective that entered into the literature in the late 1980s and early 1990s. Overall, our empirical results provide support for the stutter-step model of performance, 
as well as for alternative models that have similar behavioral predictions. They are, however, inconsistent with models that do not give a prominent role to uncertainty of beliefs in the causal processes that are presumed to generate performance in secondary schooling and in subsequent educational attainment. 


\section{REFERENCES}

Bozick, Robert, Karl L. Alexander, Doris Entwisle, Susan Dauber, and Kerri Kerr. 2010. "Framing the Future: Revisiting the Place of Educational Expectations in Status Attainment." Social Forces 88:2027-52.

Brand, Jennie E. and Yu Xie. 2010. "Who benefits most from college? Evidence for negative selection in heterogeneous economic returns to higher education." American Sociological Review 75:273-302.

Breen, Richard and John H. Goldthorpe. 1997. "Explaining Educational Differentials: Towards a Formal Rational Action Theory." Rationality and Society 9:275-305.

Carbonaro, William. 2005. “Tracking, Students' Effort, and Academic Achievement.” Sociology of Education 78:27-49.

Farkas, George, Robert P. Grobe, Daniel Sheehan, and Yuan Shuan. 1990. "Cultural Resources and School Success: Gender, Ethnicity, and Poverty Groups within an Urban School District." American Sociological Review 55:127-42.

Fredericks, Jennifer A., Phyllis C. Blumenfeld, and Alison H. Paris. 2004. "School Engagement: Potential of the Concept, State of the Evidence." Review of Educational Research 74:59109.

Gamoran, Adam and Martin Nystrand. 1992. "Taking Students Seriously." Pp. 40-61 in Student Engagement and Achievement in American Secondary Schools, edited by F. M. Newmann. New York: Teachers College Press.

Goyette, Kimberly A. 2008. "College for some to college for all: Social background, occupational expectations, and educational expectations over time." Social Science Research 37:461-484.

Grodsky, Eric and Catherine Riegle-Crumb. 2010. "Those Who Choose and Those Who Don't: Social Background and College Orientation." Annals of the American Academy of Political and Social Science 627:14-35.

Morgan, Stephen L. 1998. "Adolescent Educational Expectations: Rationalized, Fantasized, or Both?" Rationality and Society 10:131-162.

Morgan, Stephen L. 2005. On the Edge of Commitment: Educational Attainment and Race in the United States. Stanford, Calif.: Stanford University Press.

Morgan, Stephen L., Theodore S. Leenman, Jennifer J. Todd, and Kim A. Weeden. 2013. "Occupational Plans, Beliefs About Educational Requirements, and Patterns of College Entry." Sociology of Education.

Morgan, Stephen L. and Christopher Winship. 2007. Counterfactuals and Causal Inference: 
Methods and Principles for Social Research. Cambridge: Cambridge University Press.

Newmann, Fred M., Gary G. Wehlage, and Susie D. Lamborn. 1992. "The Significance and Sources of Student Engagement." Pp. 11-39 in Student Engagement and Achievement in American Secondary Schools, edited by F. M. Newmann. New York: Teachers College Press.

Pearl, Judea. 2009. Causality: Models, Reasoning, and Inference. Cambridge: Cambridge University Press.

Reynolds, John, Michael Stewart, Ryan Macdonald, and Lacey Sischo. 2006. "Have Adolescents Become Too Ambitious? High School Seniors' Educational and Occupational Plans, 1976 to 2000." Social Problems 53:186-206.

Rosenbaum, James E. 2001. Beyond College for All: Career Paths for the Forgotten Half. New York: Russell Sage Foundation.

Schneider, Barbara L. and David Stevenson. 1999. The Ambitious Generation: America's Teenagers, Motivated but Directionless. New Haven: Yale University Press.

Sewell, William H., Archibald O. Haller, and Alejandro Portes. 1969. "The Educational and Early Occupational Attainment Process.” American Sociological Review 34:82-92.

Sewell, William H., Robert M. Hauser, Kristen W. Springer, and Taissa S. Hauser. 2004. "As We Age: A Review of the Wisconsin Longitudinal Study, 1957-2001." Research in Social Stratification and Mobility 20:3-111.

Staff, Jeremy, Angel Harris, Ricardo Sabates, and Laine Briddell. 2010. "Uncertainty in Early Occupational Aspirations: Role Exploration or Aimlessness?" Social Forces 89:659-84.

Yates, Scott, Angel Harris, Ricardo Sabates, and Jeremy Staff. 2011. "Early Occupational Aspirations and Fractured Transitions: A Study of Entry into 'NEET' Status in the UK." Journal of Social Policy 40:513-34. 
Table 1. Performance Measures and the Educational Requirements of Expected Jobs Reported in the Sophomore Year of High School

(a) Performance Measures in 2002 and 2004

Standardized math test score In $2002\left(10^{\text {th }}\right.$ grade $)$

In 2004 (usually $12^{\text {th }}$ grade)

\begin{tabular}{cr} 
Mean & SD \\
\hline & \\
42.7 & 14.1 \\
48.6 & 15.2
\end{tabular}

Standardized reading test score

In $2002\left(10^{\text {th }}\right.$ grade $)$

29.8

9.8

Cumulative high school GPA

2.6

.9

(b) Educational Requirements of Expected Jobs Listed in 2002 Occupational Plans

\begin{tabular}{cc} 
Weighted \\
Weighted N & Percentage \\
\hline
\end{tabular}

Educational requirements of expected jobs

College or more

$5,287.3$

42.0

(All jobs listed require at least a college degree)

High school or less

$1,451.5$

11.5

(All jobs listed require a high school degree or less)

High school and college

495.7

(Some jobs listed require a high school degree or less

and some jobs listed require a college degree or more)

Did not list a job:

"I don't know"

$3,851.1 \quad 30.9$

(Selected as a response)

"I don't plan to work when I'm 30"

(Selected as a response)

Missing

(No response or incomplete survey)

Uncodable

$1,318.2 \quad 10.5$

(Response was uncodable)

Total

$84.5 \quad .7$

Source: Education Longitudinal Study, 2002-2006

Notes: Data are weighted (weighted N is 12,591 for 2002 math test score, the 2002 reading test score, and educational requirement of expected jobs; 11,579 for the 2004 math test score; 11,695 for

cumulative high school GPA). 
Table 2. Regression Models for Mathematics and Reading Test Scores in the Sophomore Year, with Adjustments for Family Background and Students' Own Educational Expectations

Math Test Score in 2002

Reading Test Score in 2002

Constant

\begin{tabular}{cccccc} 
Model 1 & Model 2 & Model 3 & Model 4 & Model 5 & Model 6 \\
\hline 46.26 & 8.49 & 15.40 & 32.31 & 5.83 & 10.37
\end{tabular}

Educational requirements of expected jobs:

\begin{tabular}{|c|c|c|c|c|c|c|}
\hline College or more & reference & reference & reference & reference & reference & reference \\
\hline \multirow[t]{2}{*}{ High school or less } & -7.44 & -6.26 & -4.54 & -4.85 & -3.70 & -2.58 \\
\hline & $(.49)$ & $(.45)$ & $(.44)$ & $(.33)$ & $(.31)$ & $(.31)$ \\
\hline \multirow[t]{2}{*}{ High school and college } & -3.53 & -2.54 & -2.03 & -2.04 & -1.48 & -1.16 \\
\hline & $(.74)$ & $(.64)$ & $(.65)$ & $(.53)$ & $(.45)$ & $(.45)$ \\
\hline \multirow[t]{2}{*}{ "Don’t know" } & -4.43 & -3.98 & -2.55 & -3.42 & -2.78 & -1.83 \\
\hline & $(.37)$ & $(.31)$ & $(.31)$ & $(.27)$ & $(.23)$ & $(.22)$ \\
\hline \multirow[t]{2}{*}{ "Don't plan to work at age $30 "$} & -10.55 & -7.63 & -4.47 & -9.32 & -6.99 & -4.87 \\
\hline & $(2.05)$ & $(1.48)$ & $(1.42)$ & $(1.32)$ & $(1.07)$ & $(1.06)$ \\
\hline \multirow[t]{2}{*}{ Missing } & -9.54 & -6.54 & -5.16 & -7.07 & -4.64 & -3.71 \\
\hline & $(.55)$ & $(.46)$ & $(.44)$ & $(.40)$ & $(.34)$ & $(.32)$ \\
\hline \multirow[t]{2}{*}{ Uncodable } & -11.19 & -8.78 & -7.05 & -7.30 & -5.55 & -4.39 \\
\hline & $(1.55)$ & $(1.24)$ & $(1.29)$ & $(1.13)$ & $(.98)$ & $(.97)$ \\
\hline Covariates for demographic & No & Yes & Yes & No & Yes & Yes \\
\hline \multicolumn{7}{|l|}{ Educational expectations in $10^{\text {th }}$ grade } \\
\hline Bachelor's degree or higher & -- & -- & reference & -- & -- & reference \\
\hline \multirow[t]{2}{*}{ Some college } & -- & -- & -6.97 & -- & -- & -4.29 \\
\hline & & & $(.43)$ & & & $(.31)$ \\
\hline \multirow[t]{2}{*}{ High school diploma or less } & -- & -- & -10.07 & -- & -- & -6.89 \\
\hline & & & $(.49)$ & & & $(.35)$ \\
\hline \multirow[t]{2}{*}{ Don't know } & -- & -- & -4.74 & -- & -- & -3.15 \\
\hline & & & $(.46)$ & & & $(.34)$ \\
\hline \multirow{2}{*}{$\begin{array}{l}\text { R-Squared } \\
\mathrm{N}\end{array}$} & .06 & .31 & .35 & .07 & .29 & .32 \\
\hline & 12,591 & 12,591 & 12,591 & 12,591 & 12,591 & 12,591 \\
\hline
\end{tabular}

Source: See Table 1.

Notes: Data are weighted. Robust standard errors, with an adjustment for clustering in schools, are presented in parentheses. 
Table 3. Regression Models for Mathematics Test Scores in 2004 and Cumulative Grade Point Average, with Adjustments for Family Background and Students' Own Educational Expectations

\begin{tabular}{|c|c|c|c|c|c|c|}
\hline \multirow[b]{3}{*}{ Constant } & \multicolumn{3}{|c|}{$\begin{array}{l}\text { Math Test Score in } 2004 \\
\quad \text { (usually } 12^{\text {th }} \text { grade) }\end{array}$} & \multicolumn{3}{|c|}{ Cumulative GPA in High School } \\
\hline & Model 7 & Model 8 & Model 9 & Model 10 & Model 11 & Model 12 \\
\hline & 51.52 & 7.30 & 15.57 & 2.83 & .74 & 1.23 \\
\hline \multicolumn{7}{|l|}{$\begin{array}{l}\text { Educational requirements of expected } \\
\text { jobs: }\end{array}$} \\
\hline College or more & reference & reference & reference & reference & reference & reference \\
\hline High school or less & $\begin{array}{l}-8.59 \\
(.55)\end{array}$ & $\begin{array}{l}-6.98 \\
(.50)\end{array}$ & $\begin{array}{r}-5.05 \\
(.51)\end{array}$ & $\begin{array}{r}-.490 \\
(.03)\end{array}$ & $\begin{array}{l}-.35 \\
(.03)\end{array}$ & $\begin{array}{l}-.23 \\
(.03)\end{array}$ \\
\hline High school and college & $\begin{array}{l}-3.79 \\
(.84)\end{array}$ & $\begin{array}{l}-2.92 \\
(.73)\end{array}$ & $\begin{array}{l}-2.51 \\
(.73)\end{array}$ & $\begin{array}{l}-.26 \\
(.06)\end{array}$ & $\begin{array}{l}-.19 \\
(.05)\end{array}$ & $\begin{array}{l}-.15 \\
(.05)\end{array}$ \\
\hline “Don’t know" & $\begin{array}{l}-4.78 \\
(.42)\end{array}$ & $\begin{array}{l}-4.33 \\
(.35)\end{array}$ & $\begin{array}{l}-2.72 \\
(.34)\end{array}$ & $\begin{array}{l}-.28 \\
(.02)\end{array}$ & $\begin{array}{l}-.20 \\
(.02)\end{array}$ & $\begin{array}{l}-.09 \\
(.02)\end{array}$ \\
\hline "Don't plan to work at age $30 "$ & $\begin{array}{l}-13.44 \\
(2.11)\end{array}$ & $\begin{array}{l}-10.24 \\
(1.68)\end{array}$ & $\begin{array}{l}-6.19 \\
(1.65)\end{array}$ & $\begin{array}{l}-.59 \\
(.12)\end{array}$ & $\begin{array}{l}-.36 \\
(.10)\end{array}$ & $\begin{array}{l}-.15 \\
(.10)\end{array}$ \\
\hline Missing & $\begin{array}{c}-10.35 \\
(.68)\end{array}$ & $\begin{array}{l}-7.12 \\
(.57)\end{array}$ & $\begin{array}{l}-5.65 \\
(.55)\end{array}$ & $\begin{array}{l}-.49 \\
(.04)\end{array}$ & $\begin{array}{l}-.25 \\
(.03)\end{array}$ & $\begin{array}{l}-.16 \\
(.03)\end{array}$ \\
\hline Uncodable & $\begin{array}{l}-12.34 \\
(1.86)\end{array}$ & $\begin{array}{l}-10.70 \\
(1.65)\end{array}$ & $\begin{array}{l}-8.58 \\
(1.70)\end{array}$ & $\begin{array}{c}-.53 \\
(.11)\end{array}$ & $\begin{array}{l}-.38 \\
(.11)\end{array}$ & $\begin{array}{l}-.25 \\
(.09)\end{array}$ \\
\hline $\begin{array}{l}\text { Covariates for demographic } \\
\text { characteristics, family background, and } \\
\text { school sector }\end{array}$ & No & Yes & Yes & No & Yes & Yes \\
\hline \multicolumn{7}{|l|}{ Educational expectations in $10^{\text {th }}$ grade } \\
\hline Bachelor's degree or higher & -- & -- & reference & -- & -- & reference \\
\hline Some college & -- & -- & $\begin{array}{l}-7.84 \\
(.54)\end{array}$ & -- & -- & $\begin{array}{l}-.49 \\
(.03)\end{array}$ \\
\hline High school diploma or less & -- & -- & $\begin{array}{c}-12.00 \\
(.63)\end{array}$ & -- & -- & $\begin{array}{l}-.67 \\
(.04)\end{array}$ \\
\hline Don’t know & -- & -- & $\begin{array}{l}-4.94 \\
(.52)\end{array}$ & -- & -- & $\begin{array}{l}-.43 \\
(.03)\end{array}$ \\
\hline $\begin{array}{l}\text { R-Squared } \\
\mathrm{N}\end{array}$ & $\begin{array}{c}.06 \\
11,579 \\
\end{array}$ & $\begin{array}{c}.32 \\
11,579 \\
\end{array}$ & $\begin{array}{c}.37 \\
11,579\end{array}$ & $\begin{array}{c}.05 \\
11,695 \\
\end{array}$ & $\begin{array}{c}.27 \\
11,695 \\
\end{array}$ & $\begin{array}{c}.33 \\
11,695 \\
\end{array}$ \\
\hline
\end{tabular}

Source: See Table 1.

Notes: See Table 2. 
Table 4. Regression Models with a Factor-Scored Index of Commitment as the Outcome Variable (for Comparison with the Models in Tables 4-6 and S1-S3)

Factor-Scored Index of Commitment

Constant

Educational requirements of expected jobs:

College or more

High school or less

High school and college

"Don't know"

"Don't plan to work at age 30"

Missing

Uncodable

Covariates for demographic

characteristics, family background, and school sector

Educational expectations in $10^{\text {th }}$ grade

Bachelor's degree or higher

Some college

High school diploma or less

Don't know

R-Squared

$\mathrm{N}$

Source: See Table 1.

Notes: See Table 2.

\begin{tabular}{ccc} 
Model 13 & Model 14 & Model 15 \\
\hline .21 & -1.00 & -.41
\end{tabular}

reference reference reference

$\begin{array}{lll}-.45 & -.33 & -.19 \\ (.03) & (.03) & (.03) \\ -.25 & -.18 & -.14 \\ (.06) & (.07) & (.06) \\ -.29 & -.21 & -.09 \\ (.03) & (.02) & (.02) \\ -1.05 & -.85 & -.59 \\ (.17) & (.17) & (.17) \\ -.48 & -.29 & -.17 \\ (.04) & (.03) & (.03) \\ -.40 & -.25 & -.11 \\ (.13) & (.13) & (.11)\end{array}$

No Yes $\quad$ Yes

\begin{tabular}{lcc}
-- & -- & reference \\
-- & -- & -.52 \\
& & $(.04)$ \\
-- & -- & -.86 \\
& & $(.06)$ \\
-- & -.43 \\
& & $(.04)$ \\
.04 & .16 & .23 \\
2,591 & 12,591 & 12,591 \\
\hline
\end{tabular}

.14

$-.09$

$.02)$

(.17)

$-.17$

(.03)

(.11)

Yes 
Table 5. Alternative Regression Models of Educational Performance with Adjustments for Commitment

\section{Constant}

Educational requirements of expected jobs:

College or more

High school or less

High school and college

"Don't know"

"Don't plan to work at age 30"

Missing

Uncodable

Covariates for teacher, student, and parent reports of commitment

Covariates for demographic

characteristics, family background, and school sector

Educational expectations in $10^{\text {th }}$ grade Bachelor's degree or higher

Some college

High school diploma or less

Don't know

R-Squared

$\mathrm{N}$

Source: See Table 1.

Notes: See Table 2.

\begin{tabular}{cccc} 
Math Test & Reading Test & Math Test & Cumulative \\
Score in & Score in & Score in & GPA in High \\
2002 & 2002 & 2004 & School \\
Model 3M & Model 6M & Model 9M & Model 12M \\
\hline 7.72 & 3.60 & 10.03 & .88
\end{tabular}

reference reference reference reference

$\begin{array}{llll}-3.54 & -1.97 & -3.90 & -.10 \\ (.42) & (.30) & (.48) & (.02) \\ -1.32 & -.68 & -1.87 & -.08 \\ (.60) & (.46) & (.67) & (.04) \\ -2.08 & -1.50 & -2.17 & -.04 \\ (.28) & (.22) & (.31) & (.01) \\ -2.28 & -3.36 & -3.30 & -.01 \\ (1.34) & (1.08) & (1.56) & (.12) \\ -4.25 & -3.13 & -4.66 & -.08 \\ (.41) & (.31) & (.53) & (.03) \\ -6.29 & -3.88 & -7.60 & -.22 \\ (1.28) & (.92) & (1.80) & (.08)\end{array}$

$\begin{array}{llll}\text { Yes } & \text { Yes } & \text { Yes } & \text { Yes }\end{array}$

$\begin{array}{llll}\text { Yes } & \text { Yes } & \text { Yes } & \text { Yes }\end{array}$ 
Table A1. Means and Standard Deviations of Family Background and School Sector

Variable

Mean

S.D.

Race and Gender (White and male is the reference category)

White and female

Native American and male

.01

Native American and female

.01

Asian and male

.02

Asian and female

.02

Black and male

.07

Black and female $\quad .07$

Hispanic and male $\quad .07$

Hispanic and female $\quad .08$

Multiracial male $\quad .02$

Multiracial female $\quad .02$

Urbanicity (Suburban is the reference category)

Urban

.30

Rural

Region (Midwest is the reference category)

Northeast

South

.35

West

School Sector (Public is the reference category)

Catholic

Other Private

Family Composition (Mother-father family is reference category)

Mother only family

Father only family

.03

Other family

Family Background

Mother's education (in years) $\quad 13.57$

2.35

Father's education (in years)

$13.75 \quad 2.64$

SEI score of mother's occupation in 2002 (GSS 1989 coding)

$45.51 \quad 13.01$

SEI score of father's occupation in 2002 (GSS 1989 coding)

$44.70 \quad 11.85$

Family income (natural log)

10.66

Source: See Table 1.

Notes: Data are weighted, and the $\mathrm{N}$ is 12,591 . 


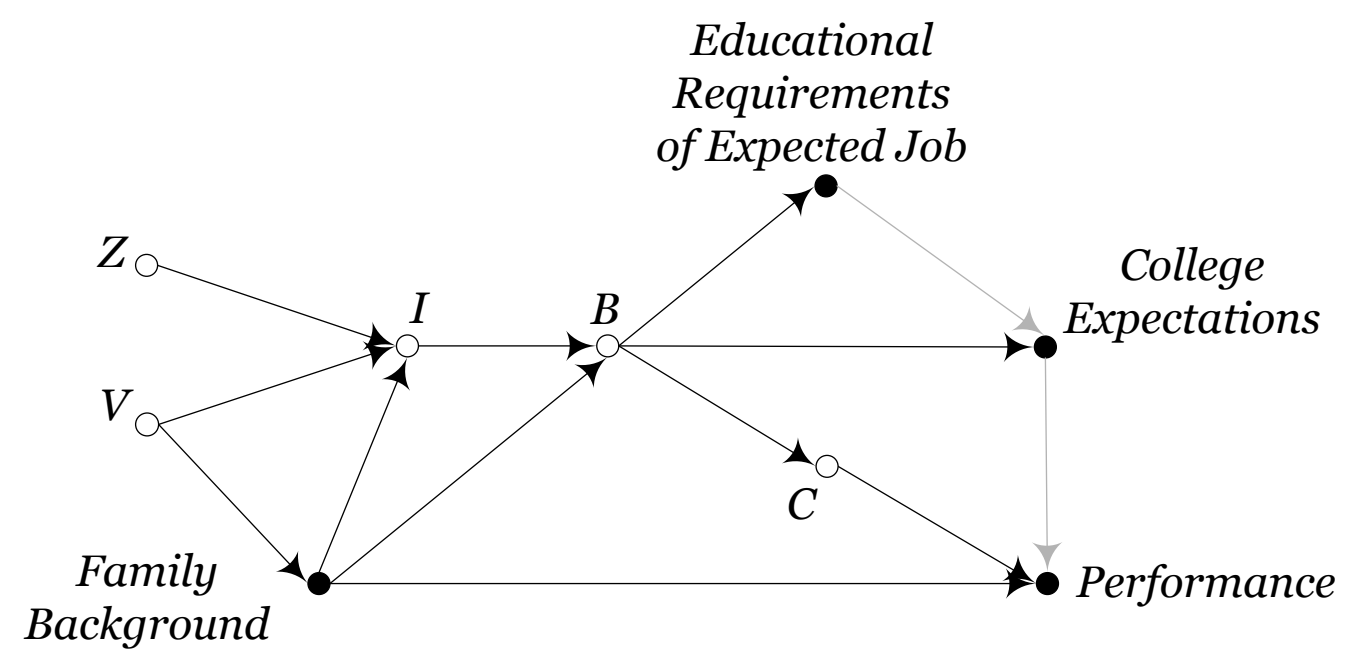

Figure 1. A conjectured stutter-step model of high school performance where information $(I)$, beliefs $(B)$, and commitment $(C)$ constitute a mechanism that determines performance 
Table S1. Coefficients for "Don't Know" and "High School and College" for Models of Teacher Perceptions of Achievement-Relevant Behavior, With and Without Adjustments for Background and School Sector

\begin{tabular}{|c|c|c|c|c|}
\hline \multirow[b]{2}{*}{ Teacher perceptions } & \multicolumn{2}{|c|}{ No Adjustments } & \multicolumn{2}{|c|}{$\begin{array}{c}\text { Adjusted by Background } \\
\text { and School Sector (see } \\
\text { Table A1) }\end{array}$} \\
\hline & $\begin{array}{l}\text { "High } \\
\text { School and } \\
\text { College" }\end{array}$ & $\begin{array}{l}\text { "Don't } \\
\text { Know" }\end{array}$ & $\begin{array}{l}\text { "High } \\
\text { School and } \\
\text { College" }\end{array}$ & $\begin{array}{l}\text { "Don’t } \\
\text { Know" }\end{array}$ \\
\hline $\begin{array}{l}\text { Does this student usually work hard for good grades in your } \\
\text { class? (English Teacher) [logit] }\end{array}$ & $\begin{array}{l}-.23 \\
(.15)\end{array}$ & $\begin{array}{l}-.51 \\
(.07)\end{array}$ & $\begin{array}{l}-.14 \\
(.06)\end{array}$ & $\begin{array}{l}-.39 \\
(.07)\end{array}$ \\
\hline $\begin{array}{l}\text { Does this student usually work hard for good grades in your } \\
\text { class? (Math Teacher) [logit] }\end{array}$ & $\begin{array}{l}-.42 \\
(.14)\end{array}$ & $\begin{array}{l}-.46 \\
(.06)\end{array}$ & $\begin{array}{l}-.37 \\
(.15)\end{array}$ & $\begin{array}{l}-.36 \\
(.07)\end{array}$ \\
\hline $\begin{array}{l}\text { How often does this student complete homework assignments } \\
\text { for your class? (English Teacher) [ordered logit] }\end{array}$ & $\begin{array}{l}-.32 \\
(.12)\end{array}$ & $\begin{array}{l}-.45 \\
(.06)\end{array}$ & $\begin{array}{l}-.25 \\
(.13)\end{array}$ & $\begin{array}{l}-.34 \\
(.06)\end{array}$ \\
\hline $\begin{array}{l}\text { How often does this student complete homework assignments } \\
\text { for your class? (Math Teacher) [ordered logit] }\end{array}$ & $\begin{array}{r}-.35 \\
(.12)\end{array}$ & $\begin{array}{l}-.14 \\
(.05)\end{array}$ & $\begin{array}{r}-.32 \\
(.12)\end{array}$ & $\begin{array}{l}-.08 \\
(.05)\end{array}$ \\
\hline $\begin{array}{l}\text { How often is this student attentive in class? (English Teacher) } \\
\text { [ordered logit] }\end{array}$ & $\begin{array}{l}-.30 \\
(.13)\end{array}$ & $\begin{array}{l}-.41 \\
(.05)\end{array}$ & $\begin{array}{l}-.23 \\
(-.14)\end{array}$ & $\begin{array}{l}-.32 \\
(.06)\end{array}$ \\
\hline $\begin{array}{l}\text { How often is this student attentive in class? (Math Teacher) } \\
\text { [ordered logit] }\end{array}$ & $\begin{array}{l}-.10 \\
(.12)\end{array}$ & $\begin{array}{l}-.17 \\
(.05)\end{array}$ & $\begin{array}{l}-.08 \\
(.12)\end{array}$ & $\begin{array}{l}-.13 \\
(.05)\end{array}$ \\
\hline $\begin{array}{l}\text { Has this student fallen behind in school work? (English } \\
\text { Teacher) [logit] }\end{array}$ & $\begin{array}{l}.37 \\
(.14)\end{array}$ & $\begin{array}{l}.47 \\
(.06)\end{array}$ & $\begin{array}{l}.30 \\
(.15)\end{array}$ & $\begin{array}{l}.37 \\
(.07)\end{array}$ \\
\hline $\begin{array}{l}\text { Has this student fallen behind in school work? (Math Teacher) } \\
\text { [logit] }\end{array}$ & $\begin{array}{c}.37 \\
(.14)\end{array}$ & $\begin{array}{l}.37 \\
(.06)\end{array}$ & $\begin{array}{c}.29 \\
(.15)\end{array}$ & $\begin{array}{l}.27 \\
(.06)\end{array}$ \\
\hline $\begin{array}{l}\text { How often is this student absent from your class? (English } \\
\text { Teacher) [ordered logit] }\end{array}$ & $\begin{array}{c}.19 \\
(.13)\end{array}$ & $\begin{array}{l}.16 \\
(.07)\end{array}$ & $\begin{array}{c}.12 \\
(.14)\end{array}$ & $\begin{array}{l}. \mathbf{1 3} \\
(.06)\end{array}$ \\
\hline $\begin{array}{l}\text { How often is this student absent from your class? (Math } \\
\text { Teacher) [ordered logit] }\end{array}$ & $\begin{array}{l}-.11 \\
(.12)\end{array}$ & $\begin{array}{l}-.07 \\
(.06)\end{array}$ & $\begin{array}{l}-.06 \\
(.12)\end{array}$ & $\begin{array}{l}-.04 \\
(.06)\end{array}$ \\
\hline $\begin{array}{l}\text { How often is this student tardy to your class? (English } \\
\text { Teacher) [ordered logit] }\end{array}$ & $\begin{array}{l}.31 \\
(.13)\end{array}$ & $\begin{array}{l}.19 \\
(.06)\end{array}$ & $\begin{array}{c}.24 \\
(.13)\end{array}$ & $\begin{array}{l}.17 \\
(.06)\end{array}$ \\
\hline $\begin{array}{l}\text { How often is this student tardy to your class? (Math Teacher) } \\
\text { [ordered logit] }\end{array}$ & $\begin{array}{l}-.37 \\
(.13)\end{array}$ & $\begin{array}{l}-.27 \\
(.06)\end{array}$ & $\begin{array}{l}-.30 \\
(.14)\end{array}$ & $\begin{array}{l}-.24 \\
(.06)\end{array}$ \\
\hline
\end{tabular}

Source: See Table 1.

Notes: Data are weighted. Robust standard errors, with an adjustment for clustering in schools, are presented in parentheses. The reference category is "college only." The type of model from which the coefficients are drawn is presented in brackets in the row labels. Coefficients are in bold if they are in the direction suggested by the stutter-step model. 
Table S2. Coefficients for "Don't Know" and "High School and College" for Models of Teacher Perceptions of Achievement-Relevant Behavior, With Additional Adjustments for Educational Expectations and for Comparison with Table S1

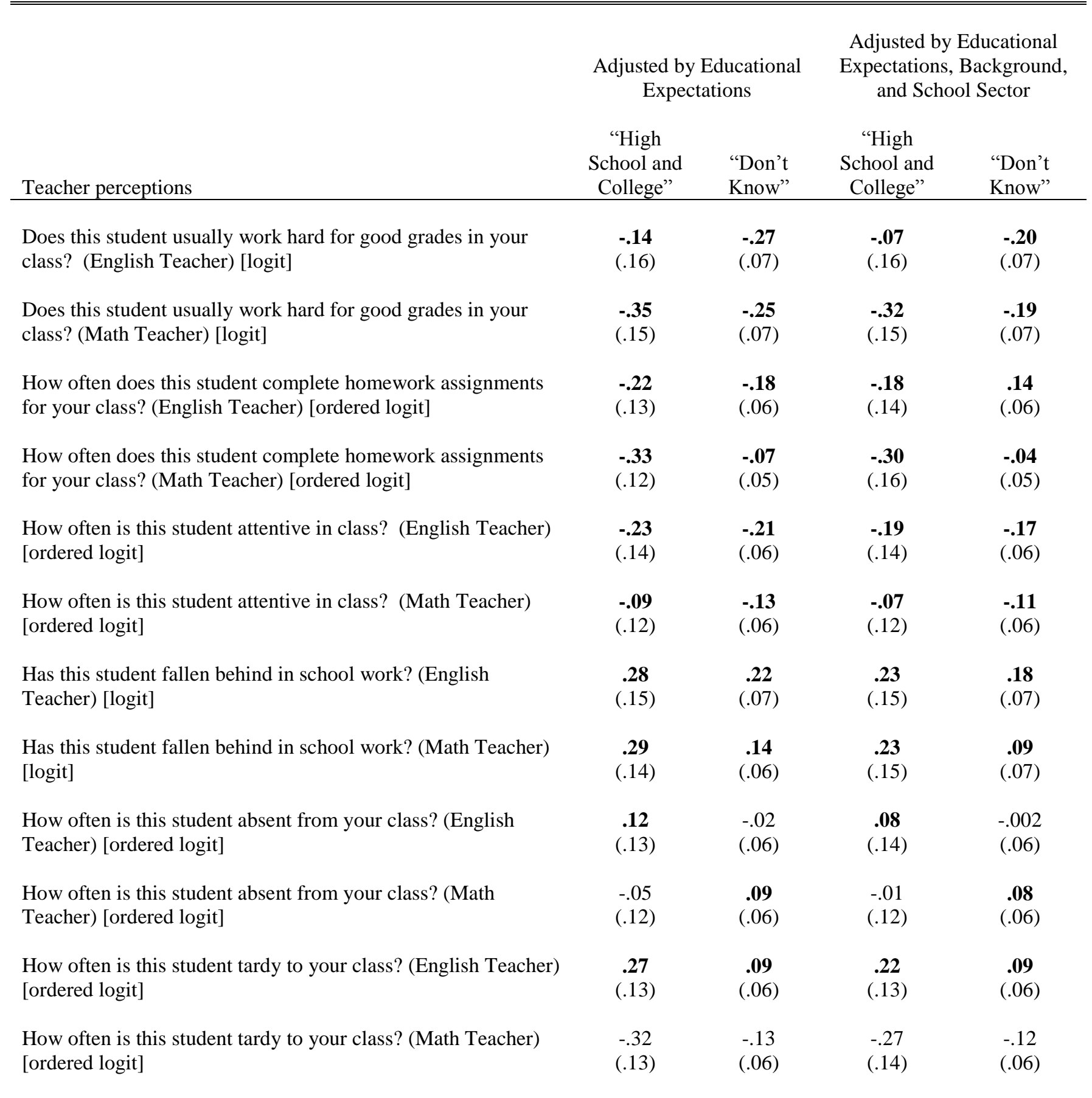

Source: See Table 1.

Notes: See Table S1. 
Table S3. Coefficients for "Don't Know" and "High School and College" for Models of Student Reports of Achievement-Relevant Behavior, With and Without Adjustments for Background and School Sector

\begin{tabular}{|c|c|c|c|c|}
\hline & \multicolumn{2}{|c|}{ No Adjustments } & \multicolumn{2}{|c|}{$\begin{array}{c}\text { Adjusted by Background } \\
\text { and School Sector (see } \\
\text { Table A1) }\end{array}$} \\
\hline & “High & & "High & \\
\hline Student reports of achievement-related behavior & $\begin{array}{l}\text { School and } \\
\text { College" }\end{array}$ & $\begin{array}{l}\text { "Don't } \\
\text { Know" }\end{array}$ & $\begin{array}{l}\text { School and } \\
\text { College" }\end{array}$ & $\begin{array}{l}\text { "Don't } \\
\text { Know" }\end{array}$ \\
\hline
\end{tabular}

How many times did the following things happen to you in the first semester or term of this school year? [ordered logit]

"I was late for school"

"I cut or skipped class"

"I got in trouble for not following school rules"

"I was transferred to another school for disciplinary reasons"

How often do you spend time on the following activities outside of school? [ordered logit]

"Visiting friends at a hangout"

"Driving or riding around"

How much do you like school? [ordered logit]

How often do you come to class without these things [ordered logit]

"Pencil/pen or paper"

"Books"

"Homework done"

How many times did the following things happen to you in the first semester or term of this school year?

"I was absent from school" (Student in 10th Grade)

"I was put on in-school suspension" (Student in 10th Grade)

"I was suspended or put on probation" (Student in 10th Grade)

$\begin{array}{cccc}\mathbf{2 9} & \mathbf{. 1 9} & \mathbf{. 2 3} & \mathbf{. 1 7} \\ (.11) & (.05) & (.11) & (.05) \\ .29 & \mathbf{. 3 0} & . \mathbf{2 2} & \mathbf{2 5} \\ (.13) & (.06) & (.13) & (.06) \\ .27 & .34 & .22 & .26 \\ (.11) & (.05) & (.11) & (.05) \\ -.85 & \mathbf{1 . 0 0} & -.91 & \mathbf{. 8 4} \\ (1.00) & (.32) & (1.04) & (.32)\end{array}$

$\begin{array}{llll}\mathbf{3 0} & \mathbf{. 0 3} & \mathbf{. 3 0} & \mathbf{. 0 2} \\ (.10) & (.05) & (.10) & (.05) \\ .15 & -.05 & \mathbf{1 8} & -.03 \\ (.10) & (.05) & (.11) & (.05) \\ \mathbf{- . 2 8} & & & \\ (.13) & \mathbf{- . 5 6} & \mathbf{- . 2 8} & \mathbf{- . 5 4} \\ & (.05) & (.13) & (.06)\end{array}$

$\begin{array}{cccc}\mathbf{. 0 8} & \mathbf{. 3 8} & \mathbf{. 0 4} & \mathbf{. 3 1} \\ (.12) & (.05) & (.12) & (.05) \\ \mathbf{. 0 3} & \mathbf{3 0} & -.02 & \mathbf{. 2 6} \\ (.12) & (.05) & (.12) & (.05) \\ \mathbf{. 1 3} & \mathbf{3 5} & \mathbf{. 1 0} & \mathbf{. 2 7} \\ (.11) & (.05) & (.11) & (.05)\end{array}$

$\begin{array}{cccc}\mathbf{1 5} & \mathbf{. 0 5} & \mathbf{. 1 5} & \mathbf{. 0 5} \\ (.10) & (.05) & (.10) & (.05) \\ \mathbf{4 5} & \mathbf{. 6 0} & \mathbf{. 3 5} & \mathbf{. 5 2} \\ (.19) & (.09) & (.19) & (.09) \\ .23 & .42 & .11 & . \mathbf{3 4} \\ (.23) & (.10) & (.24) & (.10)\end{array}$

Source: See Table 1.

Notes: See Table 4. 
Table S4. Coefficients for "Don't Know" and "High School and College" for Models of Student Reports of Achievement-Relevant Behavior, With Additional Adjustments for Educational Expectations and for Comparison with Table S3

\begin{tabular}{|c|c|c|c|c|}
\hline & $\begin{array}{r}\text { Adjusted b } \\
\text { Expe }\end{array}$ & $\begin{array}{l}\text { lucational } \\
\text { ons }\end{array}$ & \multicolumn{2}{|c|}{$\begin{array}{c}\text { Adjusted by Educational } \\
\text { Expectations, Background, } \\
\text { and School Sector }\end{array}$} \\
\hline Student reports of achievement-related behavior & $\begin{array}{l}\text { "High } \\
\text { School and } \\
\text { College" }\end{array}$ & $\begin{array}{l}\text { "Don't } \\
\text { Know", }\end{array}$ & $\begin{array}{l}\text { "High } \\
\text { School and } \\
\text { College" }\end{array}$ & $\begin{array}{l}\text { "Don't } \\
\text { Know" }\end{array}$ \\
\hline
\end{tabular}

How many times did the following things happen to you in the first semester or term of this school year? [ordered logit]

"I was late for school"

"I cut or skipped class"

"I got in trouble for not following school rules"

"I was transferred to another school for disciplinary reasons"

How often do you spend time on the following activities

outside of school? [ordered logit]

"Visiting friends at a hangout"

"Driving or riding around"

How much do you like school? [ordered logit]

How often do you come to class without these things? [ordered logit]

"Pencil/pen or paper"

"Books"

"Homework done"

How many times did the following things happen to you in the first semester or term of this school year? [ordered logit]

"I was absent from school"

"I was put on in-school suspension"

"I was suspended or put on probation"

$\begin{array}{cccc}\mathbf{. 2 6} & \mathbf{. 1 0} & \mathbf{. 2 1} & \mathbf{. 0 9} \\ (.11) & (.05) & (.11) & (.05) \\ \mathbf{2 2} & \mathbf{. 1 3} & \mathbf{. 1 7} & \mathbf{. 1 0} \\ (.13) & (.06) & (.13) & (.06) \\ . \mathbf{2 3} & \mathbf{. 1 8} & \mathbf{. 1 9} & \mathbf{. 1 2} \\ (.12) & (.05) & (.12) & (.05) \\ -.95 & \mathbf{. 6 8} & -.96 & \mathbf{5 9} \\ (1.04) & (.34) & (1.04) & (.34)\end{array}$

.28

$-.01$

$(.05)$

(.10)

$-.11$

$(.14)$

(.05)

$-.2$

$-.38$

$(.06)$

.28

$-.01$

$(.10)$

(.05)

.16

$-.08$

(.11)

(.13)

$-.24$

$-.36$

(.13)

(.06)

$\begin{array}{cccc}\mathbf{. 0 6} & \mathbf{. 2 8} & \mathbf{. 0 2} & \mathbf{. 2 4} \\ (.12) & (.05) & (.12) & (.05) \\ -.01 & \mathbf{. 2 0} & -.04 & \mathbf{. 1 7} \\ (.12) & (.05) & (.12) & (.05) \\ \mathbf{. 0 8} & \mathbf{1 9} & \mathbf{0 3} & \mathbf{. 1 5} \\ (.11) & (.05) & (.11) & (.05)\end{array}$

$\begin{array}{cccc}\mathbf{. 1 0} & -.07 & \mathbf{. 1 1} & -.06 \\ (.10) & (.05) & (.11) & (.05) \\ \mathbf{3 8} & \mathbf{. 3 2} & \mathbf{. 3 1} & \mathbf{. 3 0} \\ (.20) & (.09) & (.20) & (.09) \\ \mathbf{. 1 4} & \mathbf{1 3} & \mathbf{. 0 5} & \mathbf{. 1 0} \\ (.24) & (.11) & (.24) & (.11)\end{array}$

Source: See Table 1.

Notes: See Table S1. 
Table S5. Coefficients for "Don't Know" and "High School and College" for Models of Parent Reports of Achievement-Relevant Behavior, With and Without Adjustments for Background and School Sector

\begin{tabular}{|c|c|c|c|c|}
\hline \multirow[b]{2}{*}{ Parent reports of achievement-related behavior } & \multicolumn{2}{|c|}{ No Adjustments } & \multicolumn{2}{|c|}{$\begin{array}{l}\text { Adjusted by Background } \\
\text { and School Sector (see } \\
\text { Table A1) }\end{array}$} \\
\hline & $\begin{array}{l}\text { "High } \\
\text { School and } \\
\text { College" }\end{array}$ & $\begin{array}{l}\text { "Don’t } \\
\text { Know" }\end{array}$ & $\begin{array}{l}\text { "High } \\
\text { School and } \\
\text { College" }\end{array}$ & $\begin{array}{l}\text { "Don't } \\
\text { Know" }\end{array}$ \\
\hline $\begin{array}{l}\text { Has your tenth grader ever been considered to have a behavior } \\
\text { problem at school? [logit] }\end{array}$ & $\begin{array}{c}.36 \\
(.26)\end{array}$ & $\begin{array}{l}.47 \\
(.12)\end{array}$ & $\begin{array}{l}.23 \\
(.27)\end{array}$ & $\begin{array}{c}.33 \\
(.12)\end{array}$ \\
\hline \multicolumn{5}{|l|}{$\begin{array}{l}\text { Since your tenth grader's school opened last fall, how many } \\
\text { times have you or your spouse/partner contacted the school } \\
\text { about the following? [ordered logit] }\end{array}$} \\
\hline "Your tenth grader's problem behavior in school" & $\begin{array}{l}.57 \\
(.20)\end{array}$ & $\begin{array}{l}.39 \\
(.10)\end{array}$ & $\begin{array}{l}.43 \\
(.21)\end{array}$ & $\begin{array}{c}.32 \\
(.10)\end{array}$ \\
\hline "Your tenth grader's poor attendance record at school" & $\begin{array}{l}.003 \\
(.24)\end{array}$ & $\begin{array}{c}.32 \\
(.09)\end{array}$ & $\begin{array}{l}-.10 \\
(.25)\end{array}$ & $\begin{array}{l}.21 \\
(.10)\end{array}$ \\
\hline "Your tenth grader's poor performance in school" & $\begin{array}{l}.480 \\
(.13)\end{array}$ & $\begin{array}{l}.44 \\
(.06)\end{array}$ & $\begin{array}{l}.39 \\
(.14)\end{array}$ & $\begin{array}{l}.36 \\
(.06)\end{array}$ \\
\hline \multicolumn{5}{|l|}{$\begin{array}{l}\text { Since your tenth grader's school opened last fall, how many } \\
\text { times have you or your spouse/partner been contacted by the } \\
\text { school about the following? [ordered logit] }\end{array}$} \\
\hline "Your tenth grader's problem behavior in school" & $\begin{array}{l}.48 \\
(.20)\end{array}$ & $\begin{array}{l}.30 \\
(.09)\end{array}$ & $\begin{array}{l}.35 \\
(.21)\end{array}$ & $\begin{array}{l}.23 \\
(.10)\end{array}$ \\
\hline "Your tenth grader's poor attendance record at school" & $\begin{array}{l}.26 \\
(.19)\end{array}$ & $\begin{array}{c}.42 \\
(.09)\end{array}$ & $\begin{array}{c}. \mathbf{1 7} \\
(.20)\end{array}$ & $\begin{array}{c}.34 \\
(.09)\end{array}$ \\
\hline "Your tenth grader's poor performance in school" & $\begin{array}{c}.57 \\
(.14)\end{array}$ & $\begin{array}{c}.54 \\
(.07)\end{array}$ & $\begin{array}{c}. \mathbf{4 6} \\
(.15)\end{array}$ & $\begin{array}{c}. \mathbf{4 5} \\
(.07)\end{array}$ \\
\hline
\end{tabular}

Source: See Table 1.

Notes: See Table S1. 
Table S6. Coefficients for "Don't Know" and "High School and College" for Models of Parent Reports of Achievement-Relevant, With Additional Adjustments for Educational Expectations and for Comparison with Table S5

\begin{tabular}{|c|c|c|c|c|}
\hline \multirow[b]{2}{*}{ Parent reports of achievement-related behavior } & \multicolumn{2}{|c|}{$\begin{array}{l}\text { Adjusted with Educational } \\
\text { Expectations }\end{array}$} & \multicolumn{2}{|c|}{$\begin{array}{l}\text { Adjusted by Educational } \\
\text { Expectations, Background, } \\
\text { and School Sector }\end{array}$} \\
\hline & $\begin{array}{l}\text { "High } \\
\text { School and } \\
\text { College" }\end{array}$ & $\begin{array}{l}\text { "Don’t } \\
\text { Know" }\end{array}$ & $\begin{array}{l}\text { "High } \\
\text { School and } \\
\text { College" }\end{array}$ & $\begin{array}{l}\text { "Don’t } \\
\text { Know" }\end{array}$ \\
\hline $\begin{array}{l}\text { Has your tenth grader ever been considered to have a behavior } \\
\text { problem at school? [logit] }\end{array}$ & $\begin{array}{l}.24 \\
(.27)\end{array}$ & $\begin{array}{l}.16 \\
(.13)\end{array}$ & $\begin{array}{l}.16 \\
(.27)\end{array}$ & $\begin{array}{l}.09 \\
(.13)\end{array}$ \\
\hline \multicolumn{5}{|l|}{$\begin{array}{l}\text { Since your tenth grader's school opened last fall, how many } \\
\text { times have you or your spouse/partner contacted the school } \\
\text { about the following? [ordered logit] }\end{array}$} \\
\hline "Your tenth grader's problem behavior in school" & $\begin{array}{c}.47 \\
(.21)\end{array}$ & $\begin{array}{c}.18 \\
(.10)\end{array}$ & $\begin{array}{c}.36 \\
(.21)\end{array}$ & $\begin{array}{c}.15 \\
(.11)\end{array}$ \\
\hline "Your tenth grader's poor attendance record at school" & $\begin{array}{l}-.09 \\
(.24)\end{array}$ & $\begin{array}{c}.07 \\
(.10)\end{array}$ & $\begin{array}{l}-.16 \\
(.25)\end{array}$ & $\begin{array}{c}.03 \\
(.10)\end{array}$ \\
\hline "Your tenth grader's poor performance in school" & $\begin{array}{l}.42 \\
(.13)\end{array}$ & $\begin{array}{l}.29 \\
(.07)\end{array}$ & $\begin{array}{l}.33 \\
(.14)\end{array}$ & $\begin{array}{l}.24 \\
(.07)\end{array}$ \\
\hline \multicolumn{5}{|l|}{$\begin{array}{l}\text { Since your tenth grader's school opened last fall, how many } \\
\text { times have you or your spouse/partner been contacted by the } \\
\text { school about the following? [ordered logit] }\end{array}$} \\
\hline "Your tenth grader's problem behavior in school" & $\begin{array}{c}.40 \\
(.21)\end{array}$ & $\begin{array}{c}.07 \\
(.10)\end{array}$ & $\begin{array}{c}.29 \\
(.21)\end{array}$ & $\begin{array}{c}.05 \\
(.10)\end{array}$ \\
\hline "Your tenth grader's poor attendance record at school" & $\begin{array}{l}.14 \\
(.19)\end{array}$ & $\begin{array}{c}. \mathbf{1 5} \\
(.09)\end{array}$ & $\begin{array}{c}.09 \\
(.20)\end{array}$ & $\begin{array}{c}.13 \\
(.10)\end{array}$ \\
\hline "Your tenth grader's poor performance in school" & $\begin{array}{c}.49 \\
(.14)\end{array}$ & $\begin{array}{c}.33 \\
(.07)\end{array}$ & $\begin{array}{c}. \mathbf{4 0} \\
(.15)\end{array}$ & $\begin{array}{c}.27 \\
(.07)\end{array}$ \\
\hline
\end{tabular}

Source: See Table 1.

Notes: See Table S1. 
Table S7. Alternative Regression Models with Math Gains between 2002 and 2004 as the Outcome (for Comparison with the Models for Math Scores in 2004 as presented in Tables 3 and S6 )

Constant

Educational requirements of expected jobs:

College or more

High school or less

High school and college

"Don't know"

"Don't plan to work at age 30"

Missing

Uncodable

Covariates for demographic

characteristics, family background, and school sector

Covariates for teacher, student, and parent reports of commitment

Educational expectations in $10^{\text {th }}$ grade Bachelor's degree or higher

Some college

High school diploma or less

Don't know

\begin{tabular}{l} 
R-Squared \\
$\mathrm{N}$ \\
\hline Source: See Table 1. \\
Notes: See Table 2.
\end{tabular}

Math Test Score Gains between 2002 and 2004 (usually $10^{\text {th }}$ to $12^{\text {th }}$ grade)

\begin{tabular}{cccc} 
Model 7G & Model 8G & Model 9G & Model 9MG \\
\hline 5.18 & .25 & 1.01 & 1.35
\end{tabular}

reference reference reference reference

$\begin{array}{llll}-.86 & -.63 & -.45 & -.29 \\ (.22) & (.23) & (.23) & (.23) \\ -.37 & -.31 & -.28 & -.16 \\ (.31) & (.31) & (.31) & (.31) \\ -.20 & -.16 & -.04 & .02 \\ (.15) & (.15) & (.16) & (.16) \\ -2.00 & -1.87 & -1.46 & -1.07 \\ (.65) & (.68) & (.69) & (.69) \\ -.70 & -.53 & -.40 & -.28 \\ (.34) & (.35) & (.36) & (.35) \\ -1.84 & -1.84 & -1.67 & -1.47 \\ (.67) & (.67) & (.68) & (.72)\end{array}$

$\begin{array}{llll}\text { No } & \text { Yes } & \text { Yes } & \text { Yes }\end{array}$

$\begin{array}{lll}\text { No No No } & \text { Nos }\end{array}$

$\begin{array}{cccc}-- & -- & \text { reference } & \text { reference } \\ -- & -- & -.79 & -.45 \\ -- & -- & -1.22 & (.27) \\ & & (.29) & -.72 \\ -- & -- & -.12 & .31) \\ & & (.24) & .18 \\ & & & \\ .004 & .03 & .03 & .04) \\ 11,579 & 11,579 & 11,579 & 11,695\end{array}$


Table S8. Logit Models for On-Time High School Graduation in 2004, Estimated for All High School Sophomores in 2002

Constant

Educational requirements of expected jobs:

College or more

High school or less

High school and college

"Don't know"

"Don't plan to work at age 30"

Missing

Uncodable

Covariates for demographic

characteristics, family background, and school sector

Covariates for teacher, student, and parent reports of commitment

Educational expectations in $10^{\text {th }}$ grade Bachelor's degree or higher

Some college

High school diploma or less

Don't know

Chi-Squared

$\mathrm{N}$

Source: See Table 1.

Notes: See Table 2.
Math Test Score Gains between 2002 and 2004 (usually $10^{\text {th }}$ to $12^{\text {th }}$ grade)

\begin{tabular}{cccc} 
Model 16 & Model 17 & Model 18 & Model 18M \\
\hline 2.46 & -1.80 & -.55 & -1.18
\end{tabular}

reference reference reference reference

$\begin{array}{llll}-.75 & -.54 & -.19 & -.07 \\ (.11) & (.11) & (.12) & (.13) \\ -.45 & -.34 & -.26 & -.18 \\ (.19) & (.20) & (.20) & (.21) \\ -.72 & -.60 & -.28 & -.23 \\ (.08) & (.08) & (.09) & (.10) \\ -1.36 & -1.05 & -.49 & -.08 \\ (.31) & (.34) & (.34) & (.44) \\ -1.10 & -.71 & -.40 & -.35 \\ (.10) & (.11) & (.12) & (.13) \\ -.99 & -.72 & -.38 & -.39 \\ (.35) & (.37) & (.40) & (.48)\end{array}$

No Yes $\quad$ Yes $\quad$ Yes

$\begin{array}{llll}\text { No No } & \text { No } & \text { Yes }\end{array}$

$\begin{array}{cccc}-- & -- & \text { reference } & \text { reference } \\ -- & & & \\ & -- & (.12) & -.63 \\ -- & & -1.71 & -1.05 \\ & -- & (.11) & (.13) \\ -- & -- & -.79 & -.36 \\ & & (.13) & (.14) \\ 145.8 & 676.3 & 990.1 & 1473.0 \\ (6 d f) & (32 d f) & (35 d f) & (67 d f) \\ 12,591 & 12,591 & 12,591 & 12,591\end{array}$

